\title{
THE MAN WITH A HOLE IN HIS HEART \\ In Memory of Robert C. Solomon 1942-2007
}

$\mathrm{O}$ January 2, 2007, Robert C. (Bob) Solomon and his wife, Kathleen M. Higgins, were changing planes in Zurich on the way to Rome, when Bob grew short of breath and collapsed. He died soon after of pulmonary hypertension. Bob was born with a hole in his heart. Doctors did not expect him to live to adulthood. Perhaps as a result of this, he packed as much work, travel, friendship, and enjoyment as he could into every day. Death in an airport seemed fitting for a man who would go anywhere to give a talk - a man who had so much to say and little time.

Bob Solomon was born on September 14, 1942, in Detroit, Michigan, but grew up outside of Philadelphia with his two brothers, Jon and Andrew. His father was a lawyer and his mother an artist. In 1963, he received his B.A. in microbiology from the University of Pennsylvania. When Bob graduated, he initially pursued a medical degree at the University of Michigan before moving to the philosophy department to do graduate work in philosophy and psychology. He wrote his dissertation on unconscious motivation. After receiving his Ph.D. in 1967, Bob embraced the life of a gypsy scholar and taught philosophy in a number of schools such as Princeton, the University of Pittsburgh, Queens College, and the University of Auckland, where he periodically visited for thirty-eight years. He settled down in the philosophy department at the University of Texas, Austin, in 1973, where he was named Quincy Lee Centennial Professor and Distinguished Teaching Professor. At Texas, Bob met and married fellow philosopher - and the love of his life-Kathleen Higgins, who frequently collaborated with him on books and papers.

Anyone who knew Bob was in awe of his brilliance and productivity as a scholar. He published his first book, From Rationalism to Existentialism, in 1972 and then went on to produce over 160 articles, 28 original books, 13 edited books, and 11 textbooks, which were published in numerous editions and translated into seventeen languages. His interests were wide-ranging but his second book, The Passions (1977), sets out themes about the emotions and morality that Bob would revisit and refine throughout his career.

Philosophers knew him best for his work in continental philosophy. Bob wrote with an eloquence and wit that came from a deep understanding of his subjects. He talked about Nietzsche, Hegel, and the German romantics as if they were old friends. In one of his last articles in Chronicle of Higher Education (January 26, 2007), he refers to Heidegger and Sartre as "the grand old Mr. Cranky and Mr. Grumpy of German and French existentialism." Bob loved to teach university students and business people. His favorite course was Introduction to Philosophy, which was always packed. He recorded seven philosophy lectures for The Teaching Company's Superstar Teachers Series and he had a part in the Richard Linklater animated film, The Waking Life, starring Ethan Hawke. Psychologists who studied emotions also had great respect for Bob's work. He served as president of the International Society for Research on the Emotions from 2000-2004.

Some of Bob's biggest fans were in business ethics. He was this year's incoming president of the Society for Business Ethics. In 1985, Bob published his first business 
ethics book, It's Good Business, with his then wife Kristine Hanson. By page five, he lays down the thread that runs through all of his work on ethics: "Ethics is a way of life, a seemingly delicate but in fact very strong tissue of endless adjustments and compromises." His approach to business ethics and his own life was Aristotelian-what you are is inseparable from what you $d o$. He makes this explicit in his later books on business, Ethics and Excellence (1992) and A Better Way to Think About Business (1999).

Bob was a master in the art of friendship and he had many good friends. I met Bob in the late 1970s. We were both interested in questions about the meaning of life-questions that were not considered "serious" if you were "trained" in an analytic philosophy department in the 1960s and 1970s. A few years ago, we decided to write a textbook that covered the usual business ethics topics and also talked about the good life and the meaning of work. We invited Bob's friend and former student Clancy Martin to be a coauthor. Our book, Honest Work: A Business Ethics Reader, had a narrative in it that directly addressed students - telling them that business ethics is not as much about Enron as it is about you. Writing a book with Bob helped me understand the great joy he took in his work. We compiled the final draft of the book over a long weekend. Bob, Kathleen, and Clancy descended on our home for what I would best describe as "a work party." I can still see Bob, sitting at my kitchen table, banging on his computer with two fingers. He composed as fast as he talked. I would step out for a few minutes and when I returned, he would have written a case or an introduction. Bob worked at a fast clip, but at the end of the day, when he moved to the dining room table, a calm came over him as he turned his attention to one of his favorite pastimes - a relaxing dinner with friends.

This man with a hole in his heart seemed to write the story of how he lived and the importance of the heart in his books. Consider some of his titles: About Love, A Passion for Justice, A Passion for Wisdom, Entertaining Ideas, The Joy of Philosophy, In Defense of Sentimentality, Thinking about Feeling, Morality and the Good Life, and On Ethics and Living Well. His wife Kathleen noted that three days before Bob died, he had started writing a book about death.

While Bob never had children, he touched the lives of many people and left behind scores of students and graduate students. Days after his death, the Internet was filled with blogs of students expressing their admiration for him. Bob taught his students how to love (or at least appreciate) philosophy and apply it to their lives. He modeled the virtues he taught. A humble man with an enormous work ethic, Bob showed his graduate students that being a world-class philosopher did not entitle you to be pompous, inconsiderate, dogmatic, or too good to teach the intro course. Except for a few luxuries, like his aging green Miata, Bob was thrifty, but generous. He endowed an honors scholarship in creative arts and philosophy at the University of Texas and he also endowed a scholarship in philosophy and a tutorship at the University of Auckland.

Bob Solomon lived longer than expected, but for those of us who knew him, it wasn't long enough. Always considerate, he offers us this consolation in his book Spirituality for the Skeptic (2002). Bob writes, "Gratitude, I want to suggest, is not only the best answer to tragedies of life. It is the best approach to life itself" (p. 105). So while we will miss Bob Solomon, let us be grateful for knowing him and for the extraordinary work that he left behind.

Joanne B. Ciulla, University of Richmond 